\title{
A Somogy Megyei Kaposi Mór Oktató Kórház által bevezetett gyors reagálású rendszer hatása a kórházi mortalitásra
}

\author{
Fogas János dr. ${ }^{1}$ - Koroseczné Pavlin Rita dr. ${ }^{2}$ - Szabó Krisztina ${ }^{1}$ \\ Héra Eszter dr. ${ }^{1}$ - Repa Imre dr. ${ }^{1}$ - Moizs Mariann dr. ${ }^{1}$ \\ ${ }^{1}$ Somogy Megyei Kaposi Mór Oktató Kórház, Kaposvár \\ ${ }^{2}$ Szent István Egyetem, Kaposvári Campus, Kaposvár
}

Bevezetés: Általánosságban elmondható, hogy a fekvőbeteg-ellátást nyújtó egészségügyi intézmények intenzív terápiás osztályain (ITO) jelennek meg a legsúlyosabb kórképekkel és a legmagasabb halálozási aránnyal bíró esetek, rendszerint megkésve. Eltérően az ITO-tól, más betegellátó osztályokon előfordulhat, hogy nem észlelik megfelelően és időben a betegek olyan állapotváltozásait, melyek előre jelzik például a szívleállást vagy a keringési rendszer várható összeomlását. Ennek kiküszöbölésére jelenthet megoldást az úgynevezett gyors reagálású rendszer (RRS), melynek segítségével csökkenthető a kórházon belüli mortalitás.

Célkitưzés: A Somogy Megyei Kaposi Mór Oktató Kórház a teljes intézményre kiterjedően a 2016. évtôl alkalmazza az RRS-t. A jelen tanulmány célja a kórházi mortalitás csökkentésével kapcsolatos első eredmények bemutatása.

Módszer: Vizsgálatunkban az ITO-ra került betegek adatbázisán alapuló kereszttáblás, illetve nemparametrikus statisztikai módszereket alkalmaztuk.

Eredmények: A statisztikai próbák eredményei alapján megállapítottuk, hogy az intenzív ellátás felvételi diagnózisai (légzési elégtelenség, neurológiai ok, reanimáció, szepszis, szív/keringési, egyéb ok) között statisztikailag igazolható eltérés tapasztalható ( $\mathrm{p}=3,815 \mathrm{e}$-14) RRS alkalmazásával és a nélkül. Az RRS-sel felvettek között magasabb arányt képviseltek a légzési elégtelenséggel és szepszissel érkező, súlyosabb betegek, ugyanakkor kisebbnek bizonyult a reszuszcitáltak száma.

Megbeszélés: Az RRS nélküli időszak 2,983\%-os intézményi mortalitása az RRS-időszakban 2,932\%-ra csökkent, azonban a beküldő osztályonkénti adatokban jelentős különbségeket tapasztaltunk. 21 fekvőbeteg-osztály közül 19 osztály esetén csökkent a mortalitás az RRS bevezetését követően.

Következtetés: Arra a megállapításra jutottunk, hogy a nemzetközi szakirodalom alapján bevezetett RRS növelte az egészségügyi ellátás hatékonyságát, és ezáltal sikerült csökkenteni az intézményi szintú mortalitást.

Orv Hetil. 2021; 162(20): 782-789.

Kulcsszavak: gyors reagálású rendszer bevezetése, kórházi mortalitás, kritikus betegek ellátása

\section{Effect of rapid response system on hospital mortality, implemented by Somogy County Kaposi Mór Teaching Hospital}

Introduction: In general, the cases with the most severe diseases and highest mortality rate are admitted to the intensive care units (ICU) usually late. Contrary to ICU, in other in-patient units it can happen that those changes in patients' condition, which pre-indicate, e.g., cardiac arrest or collapse of circulatory system, are not noticed properly and in time. To eliminate this, the so-called rapid response system (RRS) can be the solution, by the help of which hospital mortality can be reduced.

Objectve: The RRS has been used all institution-wide in Somogy County Kaposi Mór Teaching Hospital from 2016. The aim of this study is to demonstrate the results concerning hospital mortality cutdown.

Method: Our analysis was based on ICU patients' database and we applied cross-tabulation and non-parametric statistical methods.

Results: We appointed, that among admission diagnosises to ICU (respiration insufficiency, neurological reason, reanimation, sepsis, cardiac/circulatory condition, other), statistically verifiable discrepancy can be experienced ( $\mathrm{p}=$ $3.815 \mathrm{e}-14$ ) with using RRS or without it. Among those admitted via RRS, more severe patients with respiration insufficiency and septic conditions were represented in higher rate, while the number of the admitted ones after resuscitation has decreased. 
Discussion: Hospital mortality rate of $2.983 \%$ without using RRS decreased into $2.932 \%$ in the period of using RRS, though we observed remarkable differences in data of non-ICU in-patient departments. Mortality has reduced in 19 in-patient departments out of 21 , after implementing RRS.

Conclusion: To sum it up, we identified that RRS implemented on the basis of international references has increased the efficiency of healthcare and owing to it, institution-level mortality has successfully decreased.

Keywords: implementation of rapid response system, hospital mortality, critical care

Fogas J, Koroseczné Pavlin R, Szabó K, Héra E, Repa I, Moizs M. [Effect of rapid response system on hospital mortality, implemented by Somogy County Kaposi Mór Teaching Hospital]. Orv Hetil. 2021; 162(20): 782-789.

(Beérkezett: 2020. október 20.; elfogadva: 2020. december 5.)

\section{Rövidítések}

APACHE $=$ (acute physiology and chronic health evaluation $)$ akut fiziológiai és krónikus állapot értékelésére kidolgozott osztályozási rendszer; COPD = (chronic obstructive pulmonary disease) krónikus obstruktív tüdőbetegség; CPR = cardiopulmonalis resuscitatio; EWS $=$ (early warning system $)$ korai figyelmeztető rendszer; EWSS = (early warning score system $)$ korai figyelmeztető pontrendszer; ITO = intenzív terápiás osztály; MET = (medical emergency team) orvosi sürgősségi csoport; NEWS $=$ (National Early Warning Score) Nemzeti Korai Figyelmeztető Pontszám (Egyesült Királyság); RRS = (rapid response system) gyors reagálású rendszer

A gyors reagálású rendszer a lényegét tekintve olyan komplex, integrált betegbiztonsági eljárási rend, mely a fekvőbeteg-ellátást nyújtó intézményekben képes a folyamatosan monitorozott betegek fiziológiai paramétereinek változásait a lehetô leggyorsabban észlelni és a bekövetkező változásokra a legrövidebb időn belül adekvát módon reagálni, mind a diagnosztika, mind a terápia tekintetében. A rendszer múködtetésének célja a kórházi halálozás csökkentése, elsősorban a cardiopulmonalis kockázati tényezők hatékony kezelése révén, valamint a súlyos szövődmények kialakulásának megakadályozása. Megjegyzendő, hogy a nemzetközi szakirodalomban a "rapid response system (RRS)”, a „medical emergency team (MET)”, valamint az „early warning score system (EWSS)" fogalmai általában szinonimaként szerepelnek, noha két eltérő múködésû rendszerről van szó a MET és az EWSS esetében. Az RRS nem más, mint e két eltérő rendszer összefoglaló elnevezése. Lényeges különbség a MET és az EWSS múködése között, hogy míg a MET esetében egy intenzív terápiás szakorvos által vezetett csapat jelenik meg mérlegelés nélkül, minden befutó jelzés alkalmával a betegnél, a szükséges mobil életmentő felszereléssel és eszközökkel felszerelten, addig az EWSS jóval összetettebb módon az észlelési szakaszban mortalitási kockázatbecslést alkalmaz. A mortalitási kockázat szempontjából három csoportba sorolja a betegeket (alacsony, közepes, magas), és az intervenciós szakasz az egyes kockázati csoportokkal korrelál. Az EWSS esetében gyakran előfordul, hogy a gyors reagálású egységet egy sürgősségi ellátásra felkészített szakdolgozó vezeti, és intenzív terápiás orvos szükség esetén avatkozik be. Az Egyesült Királyságban 2012-ben ez utóbbi rendszert integrálták a kórházi fekvőbeteg-ellátásba „National Early Warning Score (NEWS)" néven.

Az RRS megfelelő ellátásához két klinikai és két organizációs folyamat összehangolt múködésére van szükség. A két klinikai komponens az észlelési (afferens) szakaszból és az intervenciós (efferens) szakaszból tevődik öszsze, míg a két organizációs komponens a folyamatfejlesztést/minőségbiztosítást, valamint az adminisztratív tevékenységet foglalja magában. Az észlelési szakaszban a beteg fiziológiai paramétereinek (légzésszám, oxigénszaturáció, szívfrekvencia, systolés vérnyomás, tudatszint, testhőmérséklet) változásai kerülnek folyamatos rögzített monitorozásra, és az észlelt értékváltozások esetén riasztják a gyors reagálású egységet. Az intervenciós szakaszban megfelelő klinikai beavatkozás történik (diagnosztika és terápia), szükség esetén a beteg áthelyezése az ITO-ra is. A folyamatfejlesztési/minőségbiztosítási szakasz célja az RRS hatékonyságának evidenciaalapú értékelése kimeneti és folyamatmérőszámok segítségével. Ilyen mérőszámok többek között a mortalitás, a gyors reagálású egységek hívásának gyakorisága/oka/ időzítése és intézkedései.

Az adminisztratív szakaszban az RRS tervezésének, bevezetésének és fenntartásának fázisai kerülnek áttekintésre intenzív terápiás szakorvosok bevonásával. Idesorolhatók a rendszer költséghatékonyságát fókuszba állító számítások is [1].

Az első RRS-t Ausztráliában szervezték meg. Lee és mtsai 1990-ben mutatták be a MET koncepcióját a Délnyugat-Sydney-ben lévő, 375 ágyas Liverpool Hospital oktató kórházban [2]. Ezt követően a MET-rendszerrel összefüggő adatokat 1992 márciusától 1993 februárjáig prospektív módon, standardizált formában gyűjtötték. A vizsgált időszak alatt a MET-et összesen 522 alkalommal riasztották, 148 esetben (28\%) cardiopulmonalis javallat miatt. A cardiopulmonalis újraélesztésen (CPR) átesett betegek átlagos túlélési rátája kórházi tartózkodásuk ideje alatt 29\%-ra emelkedett, szemben a -42 releváns nemzetközi tudományos közlemény alapján meghatározott - 15\%-os átlaggal. 
A MET-rendszer bevezetése óta számos tanulmány igazolta pozitív hatásait a kórházi halálozások számának tekintetében. Buist és mtsai 2002-ben publikált kutatásukban, melyet az ausztráliai Dandenong Hospital-ben végeztek, arra a konklúzióra jutottak, hogy a MET bevezetésének következményeként mintegy 22\%-kal csökkent az intézmény mortalitási rátája. A nem randomizált, populációalapú kutatás a MET implementálása előtti év intézményi adatait hasonlította össze a rendszer bevezetése utáni év adataival [3].

Rinaldo Bellomo és mtsai 2003-ban közzétett kutatási eredményei szerint a MET-rendszer bevezetése után a cardiopulmonalis okokból történő halálozások száma és az általános intézményi mortalitási ráta egyaránt csökkent. A kutatás Melbourne-ben, az Austin and Repatriation Medical Centerben zajlott, és a MET bevezetése előtti 4 hónapos időintervallum intézményi adatait vetette össze egy, már a rendszer bevezetése utáni 4 hónapos periódus adataival. Az általános intézményi mortalitási arány a vizsgált időszakok tekintetében mintegy 26\%-os csökkenést mutatott [4].

Az RRS-rendszer hatékonyságát a kórházi halálozás mérséklésében a legújabb tanulmányok is egyértelmúen megerősítik. A Lee és mtsai által 2019 novemberében publikált retrospektív kutatás a Seoul National University Hospital-ben folyt 2016. július 12. és 2018. március 12. között, kizárólag felnőtt páciensek bevonásával. Az RRS alkalmazása elótti 10 hónapos periódusban bevont 4224 beteg adatait hasonlították össze a rendszer bevezetését követő, ugyanilyen hosszúságú időintervallum 4168 betegének adataival. 1000 betegre 62,3 RRS-aktiváció jutott, az indikáció 44\%-ban tachypnoe vagy hypopnoe, 31\%-ban hypoxia és 21\%-ban tachycardia vagy bradycardia volt. Az RRS bevezetése utáni időszakban szignifikánsan csökkent a kórházi halálozások száma a rendszer bevezetését megelőző időszakhoz mérten, 56,3/1000-ról 42,7/1000-es értékre [5].

A fenti pozitív eredményekkel zárult kutatások ellenére a két legnagyobb randomizált klinikai kutatás - a Medical Early Response and Intervention Trial (MERIT 2005) és az Effect of a Pediatric Early Warning System on All-Cause Mortality in Hospitalized Pediatric Patients (EPOCH 2018) - nem tudta kimutatni a kórházi halálozás egyértelmû́ csökkenését az RRS alkalmazása mellett. A 2005-ben publikált MERIT-kutatásba 23 ausztráliai kórházat vontak be, melyek közül 12 alkalmazott METrendszert. Az eredmények szerint a MET-et múködtető intézmények 1,06/1000 fós mortalitási rátája nem volt szignifikánsan alacsonyabb a rendszert nem használó 11 kórház 1,18/1000 fôs halálozási mutatójánál a váratlan elhalálozások tekintetében [6]. Bár egyértelmű, hogy kevesebb elhalálozás történt a rendszert használóknál.

A 2018-ban publikált EPOCH-kutatás az ágy melletti gyermekgyógyászati EWS hatékonyságát vizsgálta 7 ország 21 kórházában a 2011 februárja és 2015 júliusa közötti időszakban. A vizsgálat 144539 fős, legfeljebb 18 éves beteganyagra terjedt ki 559443 ápolási nap vonatko- zásában. A klinikai kutatás konklúziója szerint az ágy melletti gyermekgyógyászati EWS alkalmazása nem képes szignifikánsan csökkenteni a kórházi halálozást a vizsgált betegcsoportban, mert a rendszert nem múködtető kórházak 1,93/1000 fős mortalitási átlagához képest a rendszert alkalmazó intézmények 1,56/1000 fös mortalitási rátája közötti eltérés nem tekinthető jelentősnek [7]. Ám ebben az esetben is egyértelmúen látszik az alacsonyabb halálozási érték a rendszert használók körében.

Az először szintén 2018-ban Lyons és mtsai által publikált összefoglaló RRS-tanulmány is arra a következtetésre jutott a téma szakirodalmának áttekintő elemzése után, hogy noha az RRS alkalmazásának van néhány jelentósen pozitív kimenete, az egész rendszer alkalmazása ellentmondásos megítélésű, és az RRS további fejlesztésére van szükség a monitorozási technológiák, a kockázatjelző informatikai eszközök, valamint a humánerőforrás területén $[8]$.

Ugyancsak 2018-ban jelent meg Haegdorens és mtsai randomizált tanulmánya, amely összesen 14 belgiumi, akut ellátást nyújtó kórház 2-2 sebészeti és egyéb betegellátó osztályán vizsgálta a váratlan halálozások, a nem tervezett intenzív terápiás kezelések és a szívmegállások arányát a kontroll- és az intervenciós csoport értékeit összehasonlítva. A kontrollcsoport 34267 betegből, az intervenciós csoport 35389 betegból állt, 7 kórház 28 osztálya adatainak felhasználásával. A tanulmány konklúziója szerint nem volt kimutatható szignifikáns különbség a két csoport között, sem a váratlan elhalálozások, sem a szívmegállások, sem a nem tervezett intenzív terápiás kezelések vonatkozásában. A tanulmány szerzői azonban elismerik, hogy a váratlan halálozások és szívmegállások incidenciája a vártnál alacsonyabb volt az adatgyűjtés időszakában, ami jelentősen csökkenti a tanulmány statisztikai értékelhetőségét [9].

$\mathrm{Az}$ RRS-t negatív értelemben tárgyaló fenti tanulmányok azonban megegyeznek abban, hogy elemzéseik során bizonyos metodikai hibákat követnek el. Nem differenciálják a vizsgálatba bevont személyeket betegségcsoportok szerint, és nincsenek tekintettel arra a már 2009-ben Jones és mtsai által kimutatott fordított összefüggésre sem, amely szerint a gyors reagálású egységeket nagyobb gyakorisággal igénybe vevő kórházak esetében a mortalitási ráta jóval nagyobb mértékben csökkenthető, mint az ilyen egységeket ritkábban alkalmazó intézmények esetén. A fenti tanulmányok nincsenek tekintettel az egyes gyors reagálású egységek összetételének különbözőségeire sem, ami rendkívül lényeges tényező, hiszen statisztikailag igazolható az intenzív terápiás szakorvosok által vezetett MET-egységek nagyobb hatékonysága más megoldásokkal szemben [10].

\section{Célkitüzés}

Az RRS-nek a Somogy Megyei Kaposi Mór Oktató Kórházban történt bevezetése óta 5 év telt el, mely természetesen nem elegendő időtáv ahhoz, hogy teljes körü és 
minden részletre kiterjedő konklúziót vonhassunk le a rendszer múködésének hatékonyságával kapcsolatosan. Ahhoz azonban elegendő adat áll rendelkezésre, hogy - Magyarországon elsőként - beszámolhassunk eddig elért eredményeinkról. Tesszük mindezt a kórházi halálozás csökkentése érdekében és azért, hogy az RRS a hazai fekvőbeteg-ellátásban általánosan elterjedt és alkalmazott gyakorlattá válhasson.

A rendszer bevezetésekor és üzemeltetésekor az intézmény folyamatosan figyelembe vette a nemzetközi irodalomban fellelhető legfrissebb tanulmányokat és tapasztalatokat is [11-20].

\section{Módszer}

Az elemzés elkészítéséhez a Somogy Megyei Kaposi Mór Oktató Kórház betegadatai alapján adatbázis került kialakításra, mely a 2013 és 2018 közötti időszakra vonatkozóan anonim módon tartalmazza az alábbi adatokat:

- a beteg korát,

- a beteg nemét,

- a beteg ITO-ra történt felvételkori APACHE-értékét,

- a beteg ITO-n töltött napjainak számát,

- a beteg ITO-ellátás utáni kimenetelét,

- annak az osztálynak a megjelölését, melyról a beteg az ITO-ra érkezett,

- igen/nem jelöléssel arra vonatkozó információt, hogy több mint 48 órán át invazív lélegeztetés alatt állt-e a beteg,

- annak megjelölését, hogy RRS-en keresztül érkezett-e a beteg az ITO-ra.

Az elemzés során első lépésként az intervallumskálán mérhető adatok (APACHE-érték, ITO-n töltött napok száma) normalitásvizsgálatát végeztük el, majd a két független mintacsoportra vonatkozóan (RRS-sel érkező betegek versus nem RRS-sel érkező betegek) statisztikai próba segítségével értékeltük az adatokat. A nominális skálán mérhető adatok közti kapcsolat vizsgálatára a Pearson-féle khi-négyzet-próbát használtuk. A tesztek elvégzésére a nyílt forráskódú $\mathrm{R}$ statisztikai programcsomagot alkalmaztuk.

\section{Eredmények}

Az RRS-nek a Somogy Megyei Kaposi Mór Oktató Kórházban történt bevezetését követően statisztikai módszerekkel elemeztük a változásokat. Első lépésként az ITO adataira koncentráltunk. Megvizsgáltuk, hogy az RRS hatására miként változott az intenzív osztály betegállománya. Az adatok közül a felvételkori APACHE-érték és az intenzív osztályon töltött napok száma nem követett normáleloszlást, ezért a nemparametrikus Mann-Whitney-próbát alkalmaztuk az adatok közti eltérések vizsgálatára. A két csoport (RRS nélkül és RRS-sel érkező) adatainak mediánjára vonatkozóan végezhetjük el a statisztikai próbát, mely alapján megállapítottuk, hogy az RRS-en keresztül felvett betegek nem rendel- keztek szignifikánsan eltérő APACHE-értékkel ( $\mathrm{p}=$ 0,2662), és nem sokkal ugyan (átlagosan: RRS-betegek 9,1; nem RRS-betegek 8,6 ), de több napot töltöttek az intenzív osztályon $(\mathrm{p}=0,02096)$. Az 1 . táblázat a vizsgálatba vont két betegcsoportra vonatkozóan tartalmazza az összesített betegszámot, illetve az intervallumskálán mérhető adatok átlagos értékeit.

A minőségi változók közti (kimenetel versus RRS; ITO-ra kerülés oka versus RRS) eltéréseket khi-négyzetpróbával vizsgáltuk, és megállapítottuk, hogy az intenzív osztályon nem csökkent szignifikánsan a halálesetek száma $(\mathrm{p}=0,4439)$. Ezért a továbbiakban megvizsgáltuk, hogy mi állhat a nem várt növekedés hátterében (41\%ról 43,8\%-ra). Az ITO-ra kerülők körében nem tapasztaltunk eltérő korösszetételt, nem érkeztek magasabb APACHE-értékkel, azonban eltérő okokkal kerültek felvételre. Megállapítottuk, hogy a más kórházi osztályról az intenzív osztályra kerülés okában (légzési elégtelenség, neurológiai ok, reanimáció, szepszis, szív/keringés, egyéb) statisztikailag igazolható eltérés tapasztalható ( $\mathrm{p}=3,815 \mathrm{e}-14)$. Az RRS-betegek között ugyanis magasabb arányt képviseltek a légzési elégtelenséggel és szepszissel érkező betegek. Mindezek alapján nem meglepő, hogy kifejezetten az ITO-ra vonatkozó adatok összevetésével nem tapasztalható eltérés a mortalitásban, ugyanis teljesen más „panaszokkal” érkeztek a betegek a két vizsgált csoportban. A légzési elégtelen és a szeptikus betegek tették ki az RRS-csoport 71,7\%-át. Erről a két alcsoportról megállapítható, hogy magasabb a mortalitásuk (szepszis okozta mortalitás: 48,8\%, légzési elégtelenség okozta mortalitás: $31,4 \% ; \mathrm{p}=0,0000001038$ ), és több ápolási napot töltenek az ITO-n (szepszis, ITOnapok: 8,57; légzési elégtelenség, ITO-napok: 11,58). Mindezen túl az RRS alkalmazásának velejárója az ITO

1. táblázat |A más kórházi osztályokról ITO-ra került betegek adatai

\begin{tabular}{lcc}
\hline & RRS nélkül & $\begin{array}{c}\text { RRS-sel érkező } \\
\text { betegek }\end{array}$ \\
\hline Összes betegszám & 507 fö & 286 fö \\
Betegek átlagéletkora & 64,39 év & 64,17 év \\
Átlagos APACHE-érték & 20,2 & 19,65 \\
ITO-n töltött napok & 8,6 & 9,1 \\
száma & $41 \%$ & $43,8 \%$ \\
ITO-mortalitás & 92 & 93 \\
\hline \multicolumn{1}{c}{ ITO-ra történő felvétel oka (betegszám) } & 39 \\
\hline Légzési elégtelenség & 57 & 12 \\
Neurológia & 118 & 112 \\
Reanimáció & 146 & 23 \\
Szepszis & 63 & 7 \\
Szív/keringés & 31 & \\
Egyéb & &
\end{tabular}

APACHE = akut fiziológiai és krónikus állapot értékelésére kidolgozott osztályozási rendszer; ITO = intenzív terápiás osztály; RRS = gyors reagálású rendszer 


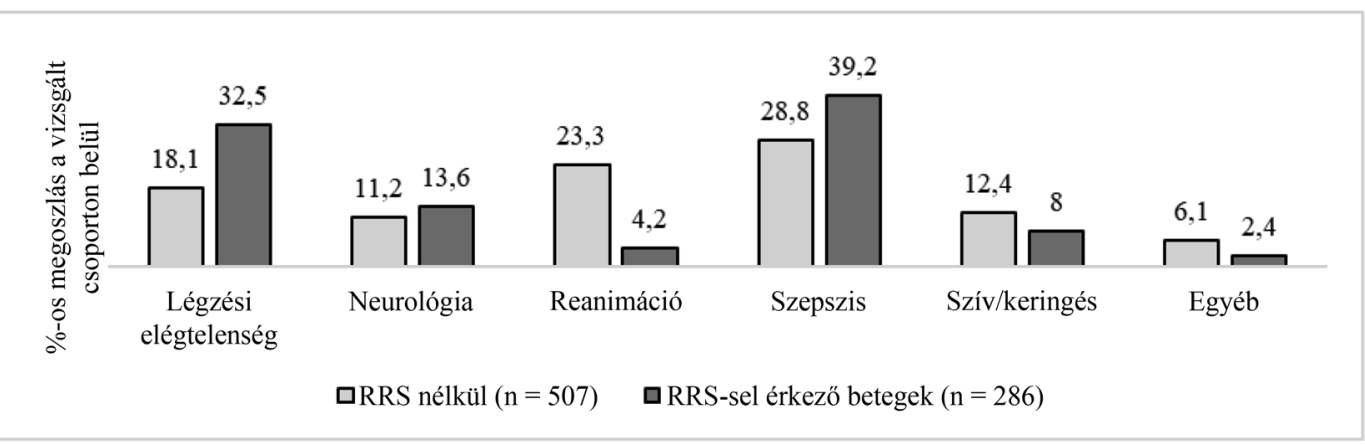

1. ábra

$\mid \begin{aligned} & \text { Az ITO-ra kerülés okainak gyakorisága RRS nélküli és RRS-betegek esetén (\%) } \\ & \text { ITO = intenzív terápiás osztály; RRS = gyors reagálású rendszer }\end{aligned}$

betegforgalmi adatainak romlása akár mortalitási, akár az ITO-n töltött ápolási napok szempontjából, ugyanis a rendszer révén a más osztályokon fekvő, időben észlelt kritikus állapotú betegek az ITO-n kerülnek további ellátásra. Magyarázatul szolgál még az is, hogy az RRS nélkül ITO-ra került betegek között szerepelnek olyan esetek is, melyek magas rizikójú mútéti vagy intervenciós beavatkozást követőleg (cardio- és neurointerventiós esetek) kerültek oda rövid intenzív terápiás időszakra.

\section{Megbeszélés}

A Somogy Megyei Kaposi Mór Oktató Kórház vezetése az intézmény intenzív terápiás szakembereivel karöltve 2014-ben azt a célt tűzte ki, hogy a kórház egészének és az egyes esetek szintjén is javítsa a betegek állapotváltozásának (fiziológiás paraméterek) észlelési minőségét, és javítsa prognózisukat. A kórházvezetés elkötelezett a több évtizedes nemzetközi tapasztalat alapján eredményesen alkalmazott RRS intézményi szinten történő adaptációja mellett, melytől a betegbiztonság és a fekvőbeteg-ellátás minőségének növelését várta. A rendszer 2015-ben három betegellátó osztályon került implementálásra, majd több lépcsőben valósult meg a kórház egészére való kiterjesztése. A 2016. év tekinthető az RRS első teljes körű alkalmazása évének, ezért elemzésünkben a 2016-2018. évi betegállomány tekinthető RRS-sel érkező betegállománynak. Mára az RRS integráns részét képezi a kórház szervezetének, és - a 2015 óta múködő OnkoNetwork rendszerhez hasonlóan eredményesen múködik. Sikeressége a jól felépített intézményi hálózaton, a csapatmunkán, a kommunikáción és a multidiszciplináris szemléleten alapul. A kórházvezetés a lehető legnagyobb támogatást nyújtotta a rendszer intézményi bevezetéséhez. Központi finanszírozás hiányában az intézmény saját erőforrásaiból hozta létre és múködteti az RRS-t, Magyarországon először és - tudomásunk szerint - egyedülálló módon. Kidolgozásra került a rendszer múködtetésének teljes dokumentációja (munkarend, ellátási protokoll, formanyomtatványok, integráció a múködési szabályzatokba és a minőségirányítási rendszerbe). Biztosítottak a szükséges infrastruk- turális, tárgyi és humánerőforrás-feltételek - csakúgy, mint a folyamatos képzés. A betegellátó osztályok együttmúködőek voltak a rendszer bevezetésében, felismerték annak hasznát és előnyeit. Közremúködésük a rendszer hatékonyságának alapja. A rendszer múködésének tapasztalatain túl szükséges megvizsgálni az első néhány év kórházi halálozási adatait. Az RRS-sel szembeni elvárás alapvetően a kórházi halálozás csökkentése, a szakirodalom alapján azonban elmondható, hogy ezt nem minden esetben lehet egyértelmúen megfigyelni. Nemzetközi szinten fóként az RRS-t használó és nem használó intézmények mortalitási adatainak összevetésével találkozhatunk, esetünkben azonban a bevezetett rendszer előtti és utáni időszak adatainak összevetése történt meg. Így elemzésünkben viszonyításként a Lee és mtsai által kimutatott 1,36\%-os mortalitási csökkenés a mérvadó.

Első lépésként kizárólag az ITO adatait vizsgáltuk meg, ugyanis a rendszerrel szemben elvárt egyik követelmény az, hogy növelje az ITO múködésének hatékonyságát. A betegállomány adatainak statisztikai elemzésével megállapítottuk, hogy az RRS bevezetése által nem csökkent szignifikánsan az ITO mortalitása, az ITO betegállománya azonban megváltozott. Az RRS nélkül a betegek egyharmada reanimáció után vagy szív-/keringési megbetegedés miatt került átvételre más osztályról az ITO-ra, míg az RRS-betegeknél ez a két átvételi indikáció mindössze a betegek 12,2 (4,2 + 8) \%-ánál jelent meg (1. ábra).

Az ITO-ra vonatkozó mortalitás változatlanságának oka abban keresendő, hogy a betegállomány az 57,7\%-os mortalitású reanimált betegcsoport felől a második legmagasabb mortalitású $(48,8 \%)$, szepszissel felvett betegek felé tolódott el (2. táblázat).

Az RRS múködése nemcsak egy osztályt (ITO) érint, hatékonyságának elemzéséhez a kórházi szintű adatokat is meg kell vizsgálni. A 286, RRS-sel érkező beteg összesen 21 más kórházi osztályról került az ITO-ra, ezért az ezekre az osztályokra vonatkozó betegforgalmi ${ }^{1}$ és halá-

Betegforgalom $=$ eltávozott betegek száma + áthelyezett betegek száma + meghalt betegek száma. 
Légzési elégtelenség

Neurológia

Reanimáció

Szepszis

Szív/keringés

Egyéb

ITO = intenzív terápiás osztály

lozási adatok alapján meghatározásra került az osztályonkénti mortalitás, melyet a 2. ábra szemléltet.

A 2. ábrán világos színnel jelölt évek mutatják az RRS nélküli vagy csak kezdetlegesen múködő RRS-évek adatait, míg sötét színnel vannak jelölve a tisztán RRS-időszakok. Az egyes évekre vonatkozóan meglehetősen változékony értékeket láthatunk (alacsony-magas értékek követik egymást), így statisztikailag igazolható eltérés nem mutatható ki. A mortalitás értékében enyhe csökkenő trend figyelhető meg, melyet a pontozott lineáris trendvonal jelöl. A 2017. évhez kapcsolódik a legmagasabb mortalitás, melynek oka a pulmonológiai és infektológiai osztályon tapasztalható növekedés. Az e két osztályra vonatkozó halálozási adatok részletes áttekintése alapján azt tapasztaltuk, hogy a COPD, illetve a tüdőgyulladás következtében elhunytak aránya növekedett, mely betegségek kezelésének hatékonysága nem függ össze az RRS múködtetésével.

A 2013-2015 és a 2016-2018 közötti időszak (mint RRS nélküli és RRS-időszak) átlagos mortalitási adatait

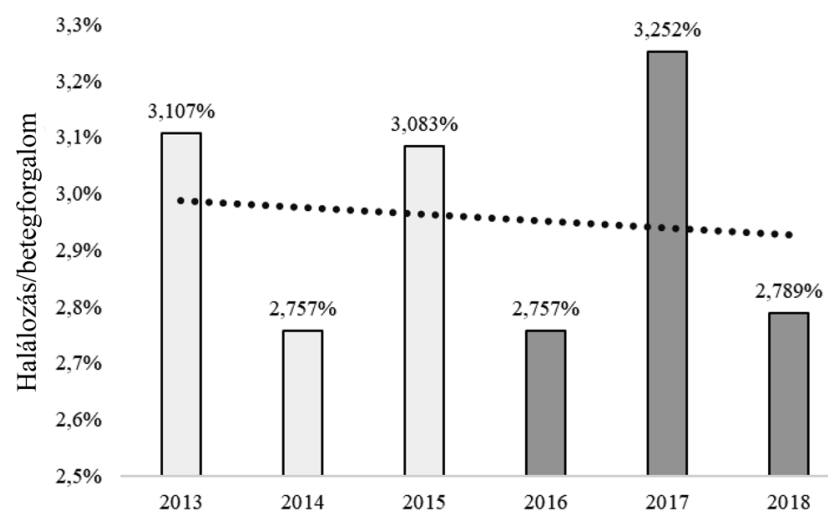

2. ábra

A mortalitás mértéke az egyes években azokon az osztályokon, ahonnan RRS-sel ITO-ra kerültek betegek

ITO = intenzív terápiás osztály; RRS = gyors reagálású rendszer

összevetve 0,05 százalékpontos csökkenést tapasztaltunk (2,983\%-ról 2,932\%-ra). Ez nem tűnik jelentékenynek a Lee és mtsai által kimutatott 1,36\%-os szignifikáns csökkenés mellett, az enyhe csökkenés mögött azonban az osztályonkénti adatokban jelentős különbségek tapasztalhatók.

A 3. ábrán a hematológiai, infektológiai, neurológiai, onkológiai, ortopédiai és pulmonológiai osztály adatait emeltük ki, tekintve, hogy esetükben volt legalább l százalékpontos a változás a két időszakot összevetve. Látható, hogy a 21 osztály közül 19 osztály esetén csökkent a mortalitás az RRS bevezetése után, azonban az infektológiai és a pulmonológiai osztály mortalitásának növe-

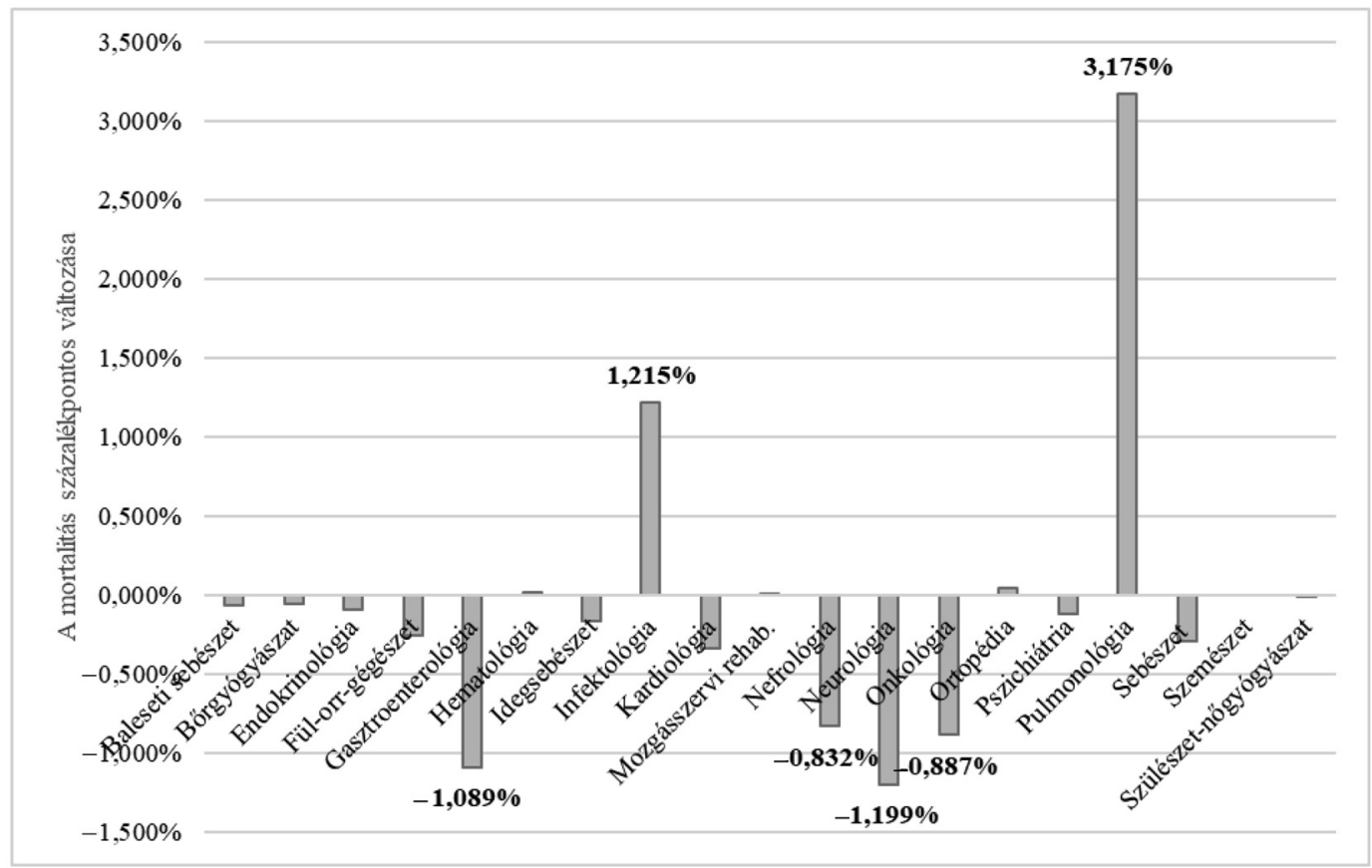

\begin{tabular}{l|l} 
3. ábra & $\begin{array}{l}\text { Az osztályonkénti mortalitási mutató értékében bekövetkezett változás mértéke az RRS-időszakban az RRS nélküli időszakhoz képest (\%) } \\
\text { RRS = gyors reagálású rendszer }\end{array}$
\end{tabular} 
kedése olyan mértékű volt, hogy a 21 osztályra vonatkozó átlagos mortalitás csak 0,05 százalékponttal tudott csökkenni.

\section{Következtetés}

A nemzetközi tapasztalatok vegyes képet mutatnak a különböző RRS-ek múködtetésének hatékonyságát illetően, ugyanis minél kiterjedtebben kerül alkalmazásra, annál költségesebb a fenntartása. A Somogy Megyei Kaposi Mór Oktató Kórház az intézményen belüli halálozás csökkentésének érdekében a 2015. évtől fokozatosan vezette be az RRS-t. A 2016. év tekinthető az első olyan időszaknak, melynek során minden kórházi osztályra kiterjedően alkalmazásra került az eljárási protokoll. Ennek segítségével a kórházi osztályokon ellátásban részesülők folyamatos monitorozása történik, és a figyelmeztető jelek első észlelése esetén riasztásra kerül az intenzív terápiás csoport. A korai észlelésnek köszönhetően sok esetben az eredeti ellátóosztályon kezelhető a beteg, ami mindamellett, hogy növeli a beteg túlélési esélyét, csökkenti az ITO terhelését. A múködés dominánsan pozitív tapasztalatai arra engednek következtetni, hogy a rendszer bevezetése sikeres volt. A pontosabb vizsgálathoz a teljes kórházi adatbázis elemzésére volt szükség. Statisztikai módszerekkel megállapítható, hogy az RRS bevezetése mellett az ITO-ra került betegösszetétel megváltozott. A reanimációt követő betegfelvétel 23,3\%-ról 4,2\%-ra csökkent. Az RRS múködésébe bevont 21 fekvőbeteg-osztály adatai alapján pedig az látható, hogy az intézmény 19 osztályán sikerült csökkenteni a mortalitást. Mindez arra enged következtetni, hogy az RRS növelte az egészségügyi ellátás hatékonyságát, és ezáltal sikerült csökkenteni az intézményi szintû mortalitást. A bemutatott eredmények alapján megfontolandó a Somogy Megyei Kaposi Mór Oktató Kórház által alkalmazott RRS-rendszer kiterjesztése más hazai, fekvőbeteg-ellátást nyújtó intézményekre a kórházi halálozás csökkentése, valamint a szakmai és múködési hatékonyság javítása érdekében.

A rendszer megalapozottságát és indokoltságát bemutató jelen közlemény után a szerzők újabb közleményben ismertetik az RRS saját protokollját, módszertanát.

Anyagi támogatás: A közlemény megírása, illetve az alapját képező és kapcsolódó kutatómunka anyagi támogatásban nem részesült.

Szerzői munkamegosztás: F. J.: A szakirodalom kutatása és feldolgozása, a kézirat megszövegezése, a kézirat elkészítésének szakmai ellenőrzése. K. P. R.: A statisztikai módszertan kidolgozása, a kézirat statisztikai elemzésének szövegezése, a mellékletek szerkesztése. Sz. K.: Az adatbázis készítése az intenzív terápiás osztály adatai alapján, a kézirat elkészítésének szakmai ellenőrzése.
H. E.: Az intézményi szintű adatok kigyújtése, a kézirat elkészítésének szakmai ellenőrzése. R. I.: A kézirat kritikus átolvasása és szakmai ellenőrzése. M. M.: A közlemény alapötlete, a rendszer intézményi bevezetője és múködtetője, a kézirat végső szövegének kialakítása, a kézirat elkészítésének szakmai ellenőrzése. A táblázatok és mellékletek kivétel nélkül saját munkák. A közlemény végleges változatát valamennyi szerző elolvasta és jóváhagyta. A közlemény nem sérti a Helsinki Deklaráció elő́rásait.

Érdekeltségek: A szerzőknek nincsenek érdekeltségeik.

\section{Irodalom}

[1] DeVita MA, Smith GB, Sheila KA, et al. "Identifying the hospitalised patient in crisis" - a consensus conference on the afferent limb of rapid response systems. Resuscitation 2010; 81: 375382 .

[2] Lee A, Bishop G, Hillman KM, et al. The medical emergency team. Anaest Intensive Care 1995; 23: 183-186.

[3] Buist MD, Moore GE, Bernard SA, et al. Effects of a medical emergency team on reduction of incidence of and mortality from unexpected cardiac arrests in hospital: preliminary study. BMJ 2002; 324: 387-390.

[4] Bellomo R, Goldsmith D, Uchino S, et al. A prospective beforeand-after trial of a medical emergency team. Med J Aust. 2003; 179: 283-287.

[5] Lee HY, Lee J, Lee SM, et al. Effect of a rapid response system on code rates and in-hospital mortality in medical wards. Acute Crit Care 2019; 34: 246-254.

[6] Hillman K, Chen J, Cretikos M, et al., MERIT Study Investigators. Introduction of the medical emergency team (MET) system: a cluster-randomised controlled trial. Lancet 2005; 365: 2091-2097.

[7] Parshuram CS, Dryden-Palmer K, Farrell C, et al. Effect of a pediatric early warning system on all-cause mortality in hospitalized pediatric patients: the EPOCH randomized clinical trial. JAMA 2018; 319: 1002-1012.

[8] Lyons PG, Edelson DP, Churpek MM. Rapid response systems. Resuscitation 2018; 128: 191-197.

[9] Haegdorens F, Van Bogaert P, Roelant E, et al. The introduction of a rapid response system in acute hospitals: a pragmatic stepped wedge cluster randomized controlled trial. Resuscitation 2018; 129: 127-134.

[10] Jones D, Bellomo R, DeVita MA. Effectiveness of the medical emergency team: the importance of dose. Crit Care 2009; 13: 313 .

[11] Gershkovich B, Fernando SM, Herritt B, et al. Outcomes of hospitalized hematologic oncology patients receiving rapid response system activation for acute deterioration. Crit Care 2019; 23: 286.

[12] Subbe CP, Bannard-Smith J, Bunch J, et al. Quality metrics for the evaluation of Rapid Response Systems: Proceedings from the third international consensus conference on Rapid Response Systems. Resuscitation 2019; 141: 1-12.

[13] Ehara J, Hiraoka E, Hsu HC, et al. The effectiveness of a national early warning score as a triage tool for activating a rapid response system in an outpatient setting: a retrospective cohort study. Medicine (Baltimore) 2019; 98: e18475.

[14] Olsen SL, Søreide E, Hillman K, et al. Succeeding with rapid response systems - a never-ending process: a systematic review of how health-care professionals perceive facilitators and barriers within the limbs of the RRS. Resuscitation 2019; 144: 75-90. 
[15] Levkovich BJ, Bingham G, Orosz J, et al. The frequency and nature of clinician identified medication-related rapid response system calls. Resuscitation 2019; 145: 75-78.

[16] The Concord Medical Emergency Team (MET) 2 Study Investigators. Outcomes following changing from a two-tiered to a three-tiered hospital rapid response system. Aust Health Rev. 2017; 43: 178-187.

[17] Kurita T, Nakada TA, Kawaguchi R, et al. Impact of increased calls to rapid response systems on unplanned ICU admission. Am J Emerg Med. 2020; 38: 1327-1331.

[18] Chalwin R, Giles L, Salter A, et al. Re-designing a rapid response system: effect on staff experiences and perceptions of rapid response team calls. BMC Health Serv Res. 2020; 20: 480.
[19] White K, Bernard A, Scott I. Derivation and validation of a risk score for predicting mortality among inpatients following rapid response team activation. Postgrad Med J. 2019; 95: 300-306.

[20] Paulson SS, Dummett BA, Green J, et al. What do we do after the pilot is done? Implementation of a hospital early warning system at scale. Jt Comm J Qual Patient Saf. 2020; 46: 207-216.

(Koroseczné Dr. Pavlin Rita, Kaposvár, Bajcsy-Zs. u. 54/B 1/3., 7400 e-mail: koroseczne.pavlin.rita@szie.hu)

\section{PÁLYÁZATI FELHÍVÁS}

\section{Gyöngyös Városi Önkormányzat pályázatot hirdet Fogszabályozási feladatok ellátására}

Gyöngyös városában, vállalkozási formában, határozatlan időre szóló feladatellátási szerződés keretében heti 16 órában, a Nemzeti Egészségbiztosítási Alapkezelő által kötött szerződés szerinti finanszírozással.

\section{Pályázati feltételek:}

- fogorvosi képesítés fogszabályozó fogorvos szakvizsgával, vagy utolsó éves jelölt a szakképzésben,

- részletes szakmai önéletrajz,

- végzettséget igazoló okmányok másolata,

- OONYI másolata,

- 3 hónapnál nem régebbi erkölcsi bizonyítvány,

- hozzájárulás a pályázati anyag elbírálásában résztvevők betekintési jogához.

A pályázat benyújtásának határideje: a felhívás megjelenésétől számított 30 nap.

\section{A pályázat elbírálásának határideje:}

a benyújtási határidőt követő soros Képviselö-testületi ülés.

A pályázat benyújtásának módja:

- postai úton, a pályázatnak a Gyöngyös Város Önkormányzata, Hiesz György polgármester részére (3200 Gyöngyös, Fö tér 13.) történő megküldésével,

- a kizárólag elektronikus úton történő jelentkezés érvénytelennek minősül.

\section{A feladat ellátásának időpontja:}

a feladat a szerződéskötést követően azonnal ellátható.

\section{További felvilágosítás kérhető:}

Gyöngyösi Közös Önkormányzati Hivatal Közigazgatási és Intézményirányítási lgazgatóság: dr. Horváth Gábor igazgatótól a 06-37/510-329 telefonon, Nagyné Szakál Mária egészségügyi referenstől a 37/510-353 telefonon vagy személyesen előzetes időpont- egyeztetést követően.

A cikk a Creative Commons Attribution 4.0 International License (https://creativecommons.org/licenses/by/4.0/) feltételei szerint publikált Open Access közlemény, melynek szellemében a cikk bármilyen médiumban szabadon felhasználható, megosztható és újraközölhető, feltéve, hogy az eredeti szerző és a közlés helye, illetve a CC License linkje és az esetlegesen végrehajtott módosítások feltüntetésre kerülnek. (SID_1) 